DOI 10.7251/SCMED1802132R

UDC 618.19-006-073

COBISS.RS-ID 7839000

\title{
Open Surgical Biopsy in Diagnosis of Mammographically Detected Suspicious Microcalcifications
}

\section{ABSTRACT}

Background: One of the earliest signs of breast cancer may be the presence of mammographically detected suspicious microcalcifications in the breast. The aim of the study was to present an open surgical biopsy of the mammographically detected suspicious microcalcifications in a breast, with preoperative wire marking of the lesions and intraoperative specimen radiography, as a reliable and valid procedure.

Material and Methods: The study included 80 female patients underwent surgery because of mammographically detected suspicious microcalcifications. The method of preoperative ultrasound-guided wire marking of a zone of microcalcification was performed in all patients. After wire marking, the control native mammography in $\mathrm{ML}$ and CC projections was performed, in order to locate the microcalcifications relative to the wire. In all patients, the extirpation of the suspicious microcalcifications was verified by the specimen radiography.

Results: In the definitive histopathological finding in situ component of ductal carcinoma of the breast was verified in nine (11,25\%) examinees. High grade in situ component was verified in eight (10\%) examinees and low grade in situ component in one examinee (1,25\%). In 11 (13,75\%) examinees, the invasive breast cancer with an extensive in situ component up to $50 \%$ was verified. In 46 $(57,5 \%)$ of the examinees, benign, non-proliferative changes were verified, while proliferative changes characterized as premalignant condition (sclerosing adenosis, radial scar and atypical ductal hyperplasia) were verified in 14 (17,5\%) examinees. Microcalcifications verified by specimen radiography are completely removed.

Conclusion: Presence of mammographically detected suspicious microcalcifications has a significant predictive value in the early detection of breast cancer. The method of an open surgical biopsy, as an alternative to stereotactic biopsy, is valid in diagnostic of the mammographically suspicious microcalcifications.

Key words: microcalcifications, US guide wire marking, open surgical biopsy, cancer, breast

(Scr Med 2018:49:132-136)

\section{Aleksandar Guzijan', Dragana Roganović ${ }^{2}$, Danijela Soprenić ${ }^{1}$}

\author{
${ }^{1}$ University clinical center of the \\ Republic of Srpska, Banja Luka, \\ Republic of Srpska, Bosnia and \\ Herzegovina \\ ${ }^{2}$ Primary healthcare centre Banja \\ Luka, Republic of Srpska, Bosnia \\ and Herzegovina \\ ${ }^{3}$ Faculty of Medicine, University of \\ Banja Luka, Banja Luka, Republic of \\ Srpska, Bosnia and Herzegovina
}

\section{Corresponding author:}

Aleksandar Guzijan

e-mail:

guzijan@hotmail.com

Manuscript received: October $8^{\text {th }}, 2018$ Manuscript accepted: November $14^{\text {th }}, 2018$ 


\section{Introduction}

The breast cancer is the most common malignant neoplasm in women. ${ }^{1}$ A mammography gives a possibility of detecting breast cancer in the early stage, when the lesion is non-palpable and when probability of cure is higher. ${ }^{2}$ In the modern age the omnipresent and growing concern because of the morbidity of breast cancer resulted in more often recommendations for screening mammography and more intense requests for biopsies of subclinical (non-palpable) lesions. ${ }^{3}$ With the introduction of screening mammography, microcalcifications are more often a mammographic characteristic of the minimal invasive breast cancer and ductal in situ cancer (DCIS). ${ }^{4}$ Using the spectrometric analysis of the samples with present microcalcifications, the group of researchers from Great Britain indicated the significant correlation between breast cancer and microcalcifications. ${ }^{5}$

On a morphological basis, we distinguish calcifications of radiologically benign characteristics and calcification of radiologically malignant characteristics. In the group of radiologically suspicious calcifications are amorphous, heterogeneous course, fine pleomorphic, fine linear and fine linear with branching. On distribution basis, we distinguish diffuse, regional, grouped, linear and segmental calcifications. ${ }^{6}$ Microcalcifications are the most commonly detected on the mammography and the most of them cannot be visualized with confidence on ultrasound. The lesions detected only on mammography require stereotactically guided biopsy and specimen radiography of the extirpated tissue samples. ${ }^{7}$ When performing a biopsy, a radiologist places the clips in order to mark the zone where the biopsy was performed. If a histopathological finding of a biopsy indicates malignancy or suspicious lesion in a breast, a surgical extirpation is indicated and the inserted clips have the purpose of locating a zone of interest for an open surgical biopsy. ${ }^{8}$

However, since the stereotactic biopsy procedure is not affordable to a larger number of patients, because of its price, an alternative to this diagnostic procedure is open surgical biopsy with preoperative wire marking of the lesion (WGL - wire guided localization). ${ }^{9,10}$ Extirpation of the suspicious microcalcifications is verified with specimen radiography in order to confirm that the area of the suspicious microcalcifications is removed. ${ }^{11}$ This procedure has its limitations too, it is indicated mostly in the suspicious microcalcifications, which are focally localized in a breast. In diffusely spreaded suspicious microcalcifications in a breast, an ultrasound-guided needle biopsy is available, if there is palpable lesion or ultrasonographic signs of suspiciousness in the zone of microcalcifications. ${ }^{12}$

\section{Material and Methods}

Retrospective - prospective study. The examined group concist of patients between 35 and 78 years, referred to mammography in the Institute of Clinical Radiology (University Clinical Centre of the Republic of Srpska UCC RS). Eighty female patients were evaluated. The average age structure of the examinees was 52 years. Digital mammography imaging was performed on GE Senographe Essential FFDM (GE Healthcare, USA). The mammography of both breasts was performed in all the patients in two standard projections (mediolateral oblique and craniocaudal). Mammogram images are analyzed according to the actual BI-RADS (Breast Imaging Reporting and Data System) classification. The study included only those patients who had suspicious microcalcifications on mammogram with or without appearance of a mass classified as BI-RADS 4 , by consensus by two radiologists. The method of preoperative ultrasonographically guided wire marking was used in all patients (Mammorep Z, Sterylab, Italy) in the area of microcalcifications.. The patient is in a lying position and the place of planned prick in the skin is disinfected with povidone iodine solution. Wire marking was ultrasound-guided (GE LOGIC 5, GE Healthcare, USA), with ultrasound probe, which was positioned on the skin and visually followed the wire introduction to the expected place of suspicious microcalcifications. After extraction of the guide, the wire is fixed to the skin with adhesive bandage. The local anesthesia was not used. After wire marking, the control mammography is made in mediolateral and craniocaudal projection in order to locate the microcalcifications against the marker (Figure 1).

\section{Figure 1. Preoperative mammography}

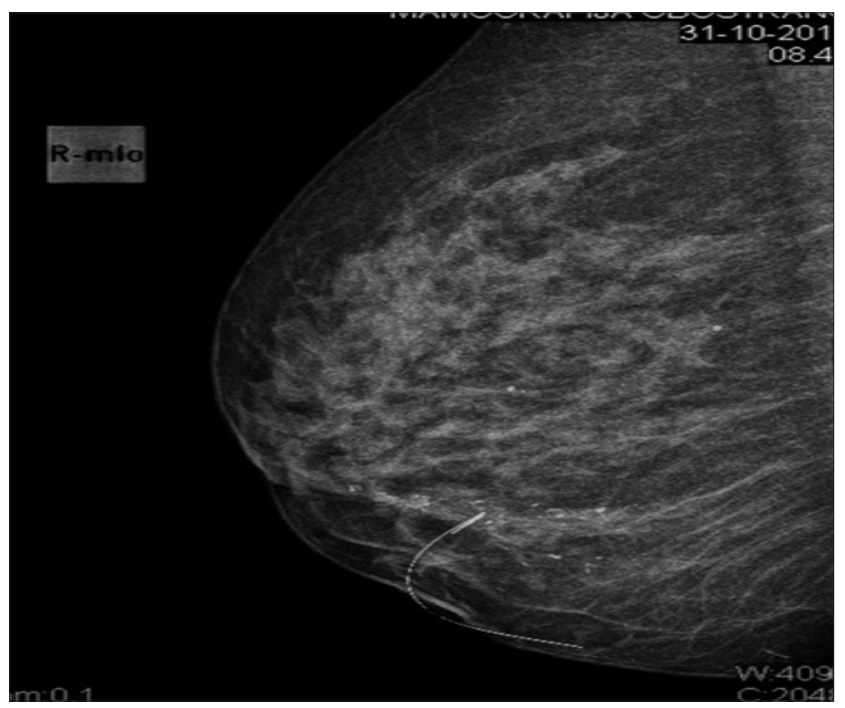

After marking out localization by measuring with 
an electronic ruler in PACS (Picture Archiving and Communication System) programme of the position of microcalcifications against the wire, the surgical procedure was performed in general endotracheal anesthesia. Intraoperatively, the extirpated breast segment, with the appropriate wire, marked with the surgical sutures, was sent to specimen radiography. Depending on technical capabilities, the preparation was sent to the specimen radiography (Figure 2 ) in a container specially intended for it (X-screen, Sterylab, Italy).

Figure 2. Specimen radiography

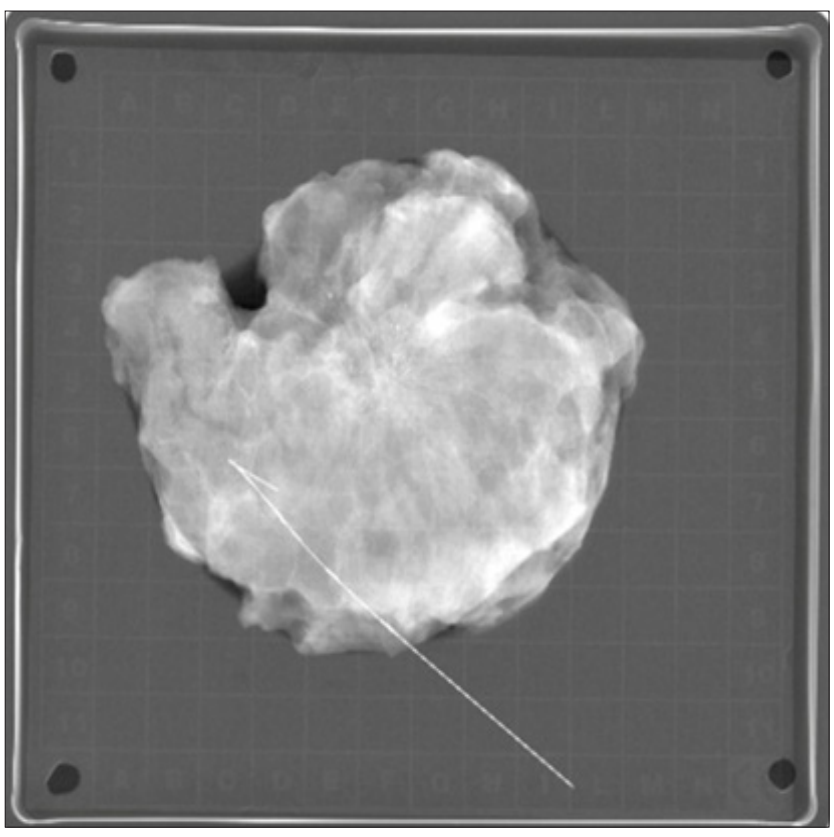

After confirmation of the suspicious microcalcifications extirpation by specimen mammography, the sample was sent for definitive histopathological analysis, fixed with $10 \%$ buffered formalin. Mammography was performed at the Institute for Clinical Radiology of the UCC RS, wire marking and surgical procedure in the Breast Centre of the UCC RS and histopathological verification in the Institute of the Clinical Pathology UCC RS. The Clinical Information System (CIS) was used for collecting the data and for archiving and processing of the radiological images PACS program was used. The data obtained were processed statistically.

\section{Results}

The most often localizations of the suspicious microcalcifications in a breast was related to upper lateral quadrant and upper quadrant compound. In $42(51,22 \%)$ examinees the mammographic suspicious microcalcifications were located in that area. Histopathological analysis of the extirpated microcalcifications is shown in the Table 1.

Table 1. Histopathological reports of the breast specimens

\begin{tabular}{|rlr|}
\hline No & \multicolumn{1}{c}{ Specimen } & Number/\% \\
\hline 1. & Fibrocystic mammary changes & $35(43.75 \%)$ \\
\hline 2. & Adenosis gl. mammae & $5(6.25 \%)$ \\
\hline 3. & Adenosis sclerosans & $11(13.75 \%)$ \\
\hline 4. & Radial scar & $3(3.75 \%)$ \\
\hline 5. & Adenosis microglandularis & $1(1.25 \%)$ \\
\hline 6. & Papillomatosis & $5(6.25 \%)$ \\
\hline 7. & DCIS High grade & $8(10 \%)$ \\
\hline 8. & DCIS Low grade & $1(1.25 \%)$ \\
\hline 9. & Ca ductale invasivum & $9(11.25 \%)$ \\
\hline 10. & Ca lobulare invasivum & $1(1.25 \%)$ \\
\hline 11. & Ca tubulolobulare invasivum & $1(1.25 \%)$ \\
& $\quad$ SUMMARY & $80(100 \%)$ \\
\hline
\end{tabular}

Based on the obtained data on the histological character of the excised changes, in $11(13,75 \%)$ patients, the invasive component of breast cancer was verified. In 9 patients, in situ component of breast cancer was found, in 8 (10\%) high grade and in one $(1,25 \%)$ low grade component. Histological analysis has shown in $14(17,5 \%)$ patients the presence of premalignant lesions such as radial scar and adenosis sclerosans. In $46(57,5 \%)$ patients, the histological analysis has shown the existence of benign lesions. During the procedure, there were no significant complications like infection or haemorrhage. Discomfort in patients during wire placing was minimal. The patients were discharged from hospital from the first to the third postoperative day. In 46 patients, where the benign breast lesion was verified, by the additional radiological control examinations, the presence of suspicious breast lesions were not found. Positive predictive value was $25 \%$ and negative predictive value $100 \%$.

\section{Discussion}

Diagnosis of breast cancer at an early stage is priceless for the final outcome in the management of patients suffering from this disease. The condition for breast cancer detection at an early stage is an adequate radiological diagnostic. Use of mammography started in 1913 when the surgeon Albert Salomon has shown his research, in which he used radiography of the mastectomy specimen in order to show the tumour spreading into axillary lymphnodes. ${ }^{13}$ By introducing 
routine mammography examinations during the 1960 s and with the development of technical characteristics of the obtained mammography image, the problem how to mark non-palpable breast lesions, for which the indication for a histological check was set, appeared. By beginning of the 1970s, the four doctors of the American hospital, independently from one another, had an idea to mark the non-palpable lesions with wire. ${ }^{14}$ Since then and until today, with gradual improvement and upgrade of the marking wire technical characteristics, the marking method of the non-palpable lesions with wire remains one of the standards in breast cancer diagnostic.

Due to the technological development and sensitivity of today's radiology analysis (ultrasound, mammography, MRI), detection of small lesions $(<1 \mathrm{~cm})$ in breast became possible. In the diagnosis of early breast cancer, this is usually the case of non-palpable breast lesions. Introduction of screening mammography lead to increase in detection of non-palpable breast lesions. ${ }^{15}$ Non-palpable lesions also include microcalcifications of suspicious mammographic characteristics. In the screening programs between 10 and $40 \%$ women are called because of microcalcifications detection. ${ }^{16}$ In that regard, detection and histopathological verification of suspicious microcalcifications, participate in early detection of breast cancer and therefore contribute to long-time survival. The recommended diagnostic method for histopathological verification of the suspicious microcalcifications is stereotactic biopsy. ${ }^{8,17}$ This method is more comfortable for patients, the surgical procedure is avoided, as well as post-operative defects on the breast, the recovery is faster and the biopsy is targeted. In the absence of this diagnostic procedure alternative is an open surgical biopsy. The open surgical biopsy has its disadvantages and limitations. In the first place, the patient is exposed to the surgical procedure, which is, per se, because of the possible post-operative complications, one kind of a risk. The open surgical biopsy has its limitations in diffusely spread microcalcifications and voluminous breasts. However, taking all into consideration, the results indicate that the open surgical biopsy, followed by specimen mammography, is a valid diagnostic procedure in histopathological verification of suspicious microcalcifications. In addition, good education and skills of the team which performs the procedure, is necessary. Our results show that, from the total number of the operated patients, in $25 \%$ malign in situ and invasive component of breast cancer was verified. The obtained data are compatible with those from the professional literature, which indicate that, in nearly $30 \%$ of suspicious microcalcifications, the malignant component of breast cancer is present. ${ }^{18}$ In examinees within which the histopathological finding indicated to benign change in the breast, by postoperative radiological follow up, new suspicious changes did not appear.

\section{Conclusion}

In circumstances when the procedure of stereotactic biopsy is unavailable, open surgical biopsy, with preoperative wire marking and specimen radiography, is a valid method in diagnostic of mammographic suspicious microcalcifications.

\section{References}

1. GLOBOCAN 2012, Cancer incidence and mortality worldwide [Internet]. Lyon, France: International Agency for research on cancer: [cited 2018 May 31]. Available from: http://globocan.iarc.fr

2. Lee CI, Elmore JG. Breast cancer screening. In: Harris JR, Lippman ME, Morrow M, Osborne CK. Disease of the breast. 5th edition. Philadephia: Wolters Kluwer Health; 2014. p 90-91.

3. Oeffinger KC, Fontham ETH, Etzioni R, Herzig A, Michaelson JS, Shih YT, et al. Breast cancer screening for women at average risk: 2015 Guideline update from the American Cancer Society. JAMA 2015;314(15):1599-614.

4. Stomper PC, Geradts J, Edge SB, Levine EG. Mammographic predictors of the presence and size of invasive carcinomas associated with malignant microcalcification lesions without a mass. Am J Roentgenol 2003;181:1679-84.

5. Baker R, Rogers KD, Shepherd N, Stone N. New relationships between breast microcalcifications and cancer. Br J Cancer 2010;103:1034-9.

6. Breast imaging lexicon: Calcifications. In: D’Orsi CJ, editor. 2013 ACR BI-RADS Atlas: Breast imaging reporting

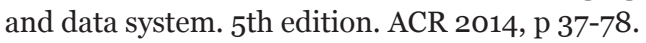

7. Dershaw DD, Liberman L. Stereotactic breast biopsy: indications and results. Oncology 1998;12(6):907-16.

8. Parker SH, Lovin JD, Jobe WE, Luethke JM, Hopper KD, Yakes WF, et al. Stereotactic breast biopsy with a biopsy gun. Radiology 1990;176:741-7.

9. Dodd GD, Fry K, Delany W. Pre-operative localization of occult carcinoma of the breast. In: Nealon TF, editor. Management of the patient with breast cancer. Philadelphia: Saunders; 1965, p 88-113.

10. Rahusen FD, Bremers AJA, Fabry HFJ, van Amerongen AH, Boom RP, Meijer S. Ultrasound-guided lumpectomy of nonpalpable breast cancer versus wire-guided resection: a randomized clinical trial. Ann Surg Oncol 2002;9:994-8.

11. Hunt KK, Robertson JFR, Bland KI. The Breast. In: Brunicardi FC, editor. Schwartz's Principles of Surgery. New York: Mc Graw Hill; 2015. p 545.

12. Querci G, Benson JR, Morgan M, Warren R, Patel A. Localization of impalpable breast lesions - a surgical approach. Eur J Surg Oncology 1996;22:478-82.

13. Gold R, Bassett L, Widoff B. Radiologic History Exhibit. RadioGraphics 1990;10(6): 1111-31. 
14. Hall FM, Kopans DB, Sadowsky NL, Homer MJ. Development of wire localization for occult breast lesions: Boston Remembrances. Radiology 2013;268:622-7.

15. Karellas A, Vedantham S. Breast cancer imaging: A perspective for the next decade. Medical Physics 2008;35(11):4878-97.

16. Domingo L, Romero A, Belvis F, Sanchez M, Ferrer J, Salas D, et al. Differences in radiological patterns, tumour characteristics and diagnostic precision between digital mammography and screen-film mammography in four breast cancer screening programmes in Spain. Eur Radiol 2011;21(9):2020-8.

17. Hunt KK, Robertson JFR, Bland KI. The Breast. In: Brunicardi FC, editor. Schwartz's Principles of Surgery. New York: Mc Graw Hill; 2015. p 529.

18. Szynglarewicz B, Kasprzak P, Biecek P, Halon A, Matkowski R. Screen - detected ductal carcinoma in situ found on stereotactic vacuum - assisted biopsy of suspicious microcalcifications without mass: radiological histological correlation. Radiol Oncol 2016;50(2):145-52.

\section{Otvorena hirurška biopsija u dijagnostici mamografski suspektnih mikrokalcifikata}

\section{SAŽETAK}

Uvod: Jedan od najranijih znakova karcinoma dojke može biti prisustvo mamografski suspektnih mikrokalcifikata u dojci. Cilj rada je da se otvorena hirurška biopsija mamografski suspektnih mikrokalcifikata u dojci, uz preoperativnu markaciju lezije žicom i intraoperativnu specimen radiografiju, prikaže kao pouzdana i validna procedura.

Materijal i metode: $U$ istraživanju je učestvovalo 80 pacijentkinja kod kojih je sproveden hirurški zahvat zbog mamografski detektovanih suspektnih mikrokalcifikata. Kod svih pacijentkinja korišćena je metoda preoperativnog markiranja žicom zone mikrokalcifikata sa ultrasonografskim navođenjem. Nakon markiranja žicom rađena je kontrolna nativna mamografija u ML i CC projekciji radi lociranja mikrokalcifikata u odnosu na žicu. Kod svih pacijentkinja ekstirpacija suspektnih mikrokalcifikata verifikovana je specimen radiografijom.

Rezultati: $U$ definitivnom histopatološkom nalazu kod devet $(11,25 \%)$ ispitanica verifikovana je duktalna in situ komponenta karcinoma dojke. U osam (10\%) slučajeva verifikovan je visoki gradus (high grade) in situ komponente, u jednom $(1,25 \%)$ slučaju niski gradus (low grade). Kod 11 (13,75\%) ispitanica verifikovan je invazivni karcinom dojke sa prisutnom ekstenzivnom in situ komponentom i do 50\%. Kod 46 (57,5\%) ispitanica verifikovane su benigne neproliferativne promene, kao i proliferativne promene okarakterisane kao prekanceroze (sklerozirajuća adenoza, radijalni ožiljak i atipična duktalna hiperplazija) kod 14 (17,5\%) ispitanica. Mikrokalcifikati su odstranjeni u celosti, što je verifikovano specimen radiografijom.

Zaključak: Prisustvo mamografski suspektnih mikrokalcifikata ima značajnu prediktivnu vrednost u otkrivanju ranog karcinoma dojke. Metoda otvorene hirurške biopsije, kao alternativne metode u odnosu na stereotaksijsku biopsiju, je validna u dijagnostici mamografski suspektnih mikrokalcifikata.

Ključne riječi: mikrokalcifikati, UZ vođeno markiranje žicom, otvorena hirurška biopsija, karcinom, dojka 